\title{
Framing "Nova Albion": Marking possession in Richard Hakluyt's The Principal Navigations, Voyages, Traffiques and Discoveries of the English Nation
}

\author{
Colm MacCrossan \\ University of Oxford
}

\begin{abstract}
This article examines the textual framing of a cluster of items in Richard Hakluyt's The Principal Navigations, Voyages, Traffiques and Discoveries of the English Nation (1598-1600) relating to the area on the Pacific coast of North America that Francis Drake named "Nova Albion." Contextualised in relation to the colonial programmes of Sir Humphrey Gilbert and Sir Walter Ralegh, it explores how a variety of editorial techniques combine to encourage a particular understanding of the history of exploration in this region that privileges English territorial claims over those of Spain. What is revealed is a delicate negotiation of the tensions raised by Hakluyt's use of pre-existing, mainly nonEnglish materials to attempt to legitimise Drake's actions by aligning them with the Spanish conquistadorial tradition, while at the same time down-playing the extent and significance of previous Spanish activity in that region.

KEYWORDS: Drake; Hakluyt; Nova Albion; paratexts; Spain; travel writing; conquest, California.
\end{abstract}

* The author is grateful for the comments of the Yearbook's Readers, and for those received at the $25^{\text {th }}$ SEDERI International Conference, Universidad de Oviedo, $14^{\text {th }}$ May 2014 .

$$
\text { (E) edert } 24 \text { (2014: 47-68) }
$$

https:// doi.org/10.34136/sederi.2014.3 
On 11 June 1578, Queen Elizabeth I of England, granted “our trustie and welbeloued seruaunt Sir Humfrey Gilbert of Compton, in our Countie of Deuonshire knight:"

free libertie and licence from time to time and at all times for euer hereafter, to discouer, finde, search out, and view such remote, heathen and barbarous lands, countreys and territories not actually possessed of any Christian prince or people $[\ldots]^{1}{ }^{1}$

Five years later, on 9 September 1583 , Gilbert was drowned while recrossing the Atlantic from Newfoundland, where he had just enacted a claim of possession over all territory within two hundred leagues of St. John's harbour on behalf of the English crown. ${ }^{2}$ The following March, fresh letters patent, with terms repeating almost word-forword those made out to Gilbert, were issued to his half-brother, the equally "trusty and welbeloued seruant Walter Ralegh Esquire." 3 For Crown purposes, Ralegh was a direct substitute for Gilbert, and his venture essentially a continuation of Gilbert's existing project. ${ }^{4}$

The similarity of the two patents indicates the degree to which those directing English overseas ventures were sensitive to the formalities of legal precedent. Yet they do not signal complete submission by the English queen - and head of the Protestant Church of England - to the terms of Pope Alexander VI's 1493 bull Inter caetera. ${ }^{5}$ This divided the world beyond Europe longitudinally

${ }^{1}$ Unless otherwise stated, quotations in this essay are from Hakluyt (1598-1600), hereafter PN2. For Hakluyt's transcription of Gilbert's patent see: PN2 III:135-137 (135).

${ }^{2}$ For an account of Gilbert's final voyage see: PN2 III:143-161.

${ }^{3}$ For Hakluyt's transcription of Ralegh's patent see: PN2 III:243-245 (243). Unless otherwise stated, quotations representing both the Gilbert and Ralegh patents are from Ralegh's.

${ }^{4}$ Only two substantive differences exist between the two patents. Ralegh's patent expands Gilbert's relatively general claim to "all commodities, iurisdictions and royalties" to specify additional title over "prerogatiues ... priuiledges, franchises, and preeminences," suggesting a development in thinking about how colonial rights could be exploited financially. A further change redefines the territory available to the patentee from lands "not actually possessed of any Christian prince or people" (in Gilbert's patent) to those "not actually possessed of any Christian prince, nor inhabited by Christian people" (in Ralegh's), emphasising the Crown's sole authority in determining matters of sovereign "possession," while restricting its subjects to the more subordinate acts of "inhabiting."

${ }^{5}$ For a summary of the weakening of papal authority in relation to issues of sovereignty, see MacMillan (2006:18-25). 
between Spain (to the west) and Portugal (to the east), with the precise line of division set by those two countries the following year, in their bilateral Treaty of Tordesillas, at 370 leagues west of the Cape Verde islands. These agreements sought to settle sovereignty over future discoveries as well as past, but the Gilbert and Ralegh patents' insistence on the criterion of actual "possession" created scope (at least in English minds) for the establishment of English authority in places not yet visited or made subject to sustained occupation by its Iberian rivals.

Nonetheless, having been issued during a period in which England had not yet openly committed itself to conflict with Spain (which, from 1580, also held the crown of Portugal), the patents' explicit commitment to respect the pre-existing claims of "any Christian Prince being in amitie with vs" effectively restricted would-be English planters to those more northerly latitudes where no European presence had yet taken root. ${ }^{6}$ Most of this early English activity (including Gilbert's and Ralegh's) concentrated on locations along the Atlantic seaboard that could be reached directly without encountering Spanish resistance. However, it was the first, surprising penetration into the Pacific by an English force, under the command of the as-yet un-knighted Francis Drake, that inspired the specific territorial controversy on which this article will focus, one which highlights the subtlety and sensitivity of Elizabethan England's negotiation of the issue of Spanish imperial precedence.

The texts of the Gilbert and Ralegh patents quoted above, and the narratives relating to Drake to which I now turn, were published together in 1600 by the English clergyman and colonial advocate Richard Hakluyt, in the third volume of the second, much-enlarged edition of his immense travel compendium The Principal Navigations, Voyages, Traffiques and Discoveries of the English Nation. ${ }^{7}$ This work emerged in a much different political context to that in which the patents had been first granted. England's intervention in support of the Dutch Revolt in 1585 had been followed by over a decade of "obstinately undeclared" naval warfare (Elliott 1968:312-313). This

\footnotetext{
${ }^{6}$ Versions of this formula also occur in a number of related narratives and discussions in The Principal Navigations. See PN2 III:135, 143, 146, 178, 180, 243, 279, and 661.

7 Transcriptions of both patents had also previously appeared in the first, shorter edition of Hakluyt's Principall Navigations, but most of the other material discussed below did not. See Hakluyt (1589:677-679, 725-728); hereafter PN1.
} 
included a series of Spanish Armadas being sent toward England (1588, 1596 and 1597), a similar number of large-scale English attacks on Cadiz (1587, 1596) and Spanish-ruled Lisbon (1589), numerous more-ambiguously-defined raids by Englishmen in the West Indies, and endless skirmishes between various English and Spanish ships in the Atlantic and the Mediterranean. The criterion of England and Spain being "in amitie" was therefore very much open to question. Yet for all of this Anglo-Spanish antagonism, Spain's dominant position on both sides of the Atlantic had still not yet been seriously challenged. The 1589 Portugal expedition, launched to capitalise on the momentum of the previous year's Armada defence, failed either to permanently cripple Spain as a naval power or to effectively promote internal dissension on the Iberian Peninsula. ${ }^{8}$ Equally, in the two decades since the Gilbert and Ralegh patents had been issued, England had still failed to establish a single successful colony on the western side of the Atlantic. Since England was as yet unable to impose itself as a de facto authority in the New World, any claim its proponents hoped to make over territory there still had to be presented in de jure form - albeit with no fixed authority having yet replaced the papacy's former role in determining such disputes. ${ }^{9}$

This delicate situation is reflected in several aspects of Hakluyt's handling of the Anglo-Spanish contest in the third volume of The Principal Navigations, dealing with voyages to "all parts of the Newfound World of America, or the West Indies" (PN2 III: Title page). The volume's dedicatory epistle demands "a good and Christian peace" with Spain, while at the same time presenting its contents as contributing to the ongoing war effort: "I haue vsed the vttermost of my best endeuour, to get, and hauing gotten, to translate out of Spanish, and here in this present volume to publish such secrets of theirs, as may any way auaile vs or annoy them" (PN2 III: Sig. A2v). Hakluyt's editorial activity is presented in terms which, as Mary Fuller notes, "put it in the same category of difficulty and effort as that actual voyaging which he never performed" (1995:153). The publication of Spanish "secrets" - including two "ruttiers" or confidential navigational guides to the West Indies, at the end of a section detailing over three decades of illicit English

\footnotetext{
${ }^{8}$ On the aims of the Portugal expedition, see Wernham (1951).

${ }^{9}$ For Hakluyt's rejection of the bull Inter caetera, and of papal authority more generally in determining sovereignty over the sea, see Pirillo (2012:181-82).
} 
trade and plunder in this region - is presented by Hakluyt as a personal intervention in the conflict between the two sides ( $\mathrm{PN}_{2}$ III:603-613, 613-627).

Yet Hakluyt also knew that his country could not impose its will on Spain by force with any certainty. Weaker economically and unproven as a military aggressor, England could not yet forsake subtler methods of establishing territorial claims in the New World. Hakluyt was not new to either geopolitics or propaganda. As chaplain to the English ambassador in Paris between 1584 and $1589-$ during which years the proxy war in the West Indies transferred into open conflict in European seas and ports - he reported regularly to Elizabeth's Principal Secretary (and chief spy-master) Sir Francis Walsingham on matters including the activities there of the former Spanish ambassador to England, Bernardino de Mendoza. ${ }^{10}$ Over the same period, Hakluyt was directly involved with Ralegh's Virginia enterprise, contributing a considerable amount of promotional material including the extensive manuscript prospectus now known as "The Discourse of Western Planting," which he presented in person to Elizabeth in October 1584 (Hakluyt 1993).

The "Discourse" is a sustained piece of original writing - the longest such piece Hakluyt is known to have produced. This makes it an entirely different kind of work to The Principal Navigations, which loosely re-packages around six hundred mainly independently-produced travel narratives and documents into regionally-defined, chronologically-ordered sequences. In composing the former, Hakluyt had available to him all the rhetorical strategies that a "sometime Master of Arts" at Oxford will have been trained to use. ${ }^{11}$ However, as editor rather than author of the latter, his influence over its final text was necessarily exerted in a much different manner - principally via the hints he could insert at various points in the paratext, the text around the text such as intertitles and marginal notes (MacCrossan 2012:139-151). In the case

\footnotetext{
${ }^{10}$ For details of this relationship, culminating in Hakluyt's dedication of the first edition of The Principall Navigations to Walsingham in 1589, and of Hakluyt's other activities during this period, see D.B. and A.M. Quinn's "A Hakluyt Chronology." (1974a:1:277-303).

${ }^{11}$ For a discussion of Hakluyt's use of the authorial freedom afforded by the "Discourse" format in constructing an anti-Spanish colonial programme, see Borge (2012).
} 
of a particular five-item cluster of texts, centred on activities on the west coast of North America, an especially intensive form of paratextual framing can be detected. The organisation and presentation - and, in a sense, even the very existence - of this cluster reflects the sensitivity of the legal pressures surrounding England's relatively late entry into New World colonisation.

David Quinn has described Hakluyt's first collection of voyaging material, Diuers Voyages Touching the Discouerie of America (1582), as an attempt "to establish the English title to North America as a next step towards the justification of the Gilbert enterprise" (1967:30). He suggests that the components of Diuers Voyages are arranged into a "logical sequence," the conclusion of which is the justice of the English territorial claims (30). Just such a "logical sequence" appears to be in place in the section of the third volume of The Principal Navigations documenting early Spanish expeditions northwards beyond the Pacific coast of Mexico, and Drake's later passage in the same direction during his circumnavigation of $1577^{-}$ 1580. A number of deviations from Hakluyt's standard model of arranging largely unmediated second-hand texts in strict chronological order together suggest that this whole section has been constructed specifically in order to bolster the legal status of England's claim to sovereignty (through Drake) against that of Spain (through two conquistadors from the time of Cortés). This is partly a matter of selection, but also reflects specific interventions into the text which add significant emphasis to the English claim.

If the narratives of Drake's circumnavigation are accurate, he and his men arrived at "Nova Albion," a site on the Pacific coast of North America previously unvisited by Europeans, on 17 June $1579 .{ }^{12}$ Within a few days, the reports indicate, and at the request of the indigenous people, "in the name, and to the vse of Her Maiestie, he tooke the scepter, crowne and dignitie of the said Countrey in his hands" (PN2 III:442). Preceding by several years Gilbert's disastrous voyage to Newfoundland, this was England's first formal claim to an American possession. ${ }^{13}$ A narrative of the whole circumnavigation,

\footnotetext{
${ }^{12}$ The focus of this article is textual rather than historical. It therefore makes no attempt to establish the actual site of Nova Albion, or to judge between the many detailed investigations that have been made into this issue.

${ }^{13}$ Although Gilbert had by this date been in possession of his patent for a year, Drake could have had no knowledge of this fact, having left England on 13 December 1577.
} 
"The famous voyage of Sir Francis Drake into the South sea, and therehence about the whole Globe of the earth, begun in the yeere of our Lord, 1577," appeared as a late addition to the first edition of The Principall Navigations, and was reprinted in the second edition ( $P N_{1}$ 643A-L; PN2 III:730-742). The second edition also privileges the Nova Albion leg of Drake's expedition by reproducing the extract describing it as a stand-alone narrative, re-contextualised within a discrete section (PN2 III:397-447). ${ }^{14}$

A freshly-devised intertitle for this newly-separate item summarises the who, where, what, why, and how of the events it describes:

The course which Sir Francis Drake held from the hauen of Guatulco in the South sea on the backe side of Nueua Espanna, to the Northwest of California as far as fourtie three degrees: and his returne back along the said Coast to thirtie eight degrees: where finding a faire and goodly hauen, he landed, and staying there many weekes, and discouering many excellent things in the countrey and great shewe of rich minerall matter, and being offered the dominion of the countrey by the Lord of the same, hee tooke possession thereof in the behalfe of her Maiestie, and named it Noua Albion. (PN2 III:440)

Although the agent here is Drake, the intertitle - with care reminiscent of the alteration in Ralegh's patent to distinguish the sovereign right of "possessing" from the subordinate, practical business of "inhabiting" - makes clear that the ultimate beneficiary is Elizabeth I. The location is at 38 degrees of northerly latitude, the territory is "rich" and "excellent," and the submission is voluntary, but also cemented by an explicit performative speech-act: an act of naming. This intertitle thus introduces a number of ways in which the narrative operates within the conventions established over the preceding decades of Spanish conquest in the New World. The naming of "Nova Albion" referred to at the end of the intertitle has a clear model in Spanish Imperial practice, dating back to Columbus's foregrounding of this ritual when encountering a new island during his first voyage ("and so to each one I gave a new name") (Jane

\footnotetext{
${ }^{14}$ The "Nova Albion" narrative ( $P N_{2}$ III:440-442) is drawn from the part of the "Famous Voyage" narrative found at $P N_{1} 643$ G-I and PN2 III:736-738.
} 
1988:2). ${ }^{15}$ Similarly, in the wake of Spain's geopoliticallytransformative extractions of gold and silver in South America, the promise of "rich minerall matter" is plausible and attractive. It is also essential in attempting to draw investment, whether state or private, for future expeditions to make permanent Drake's claim of "dominion." Since Drake himself - the individual to whom the residents reportedly "did set the crowne vpon his head, inriched his necke with all their chaines" - had died in the interim, the outcome of such a venture would be less predictable, and would have to be extremely lucrative to be an attractive investment - more so than, say, the raiding of ships and towns on which Drake himself and others such as the "Privateering" Earl of Cumberland had focused in intervening years. But most urgently, the intertitle foregrounds the issue of the legal status of Nova Albion at the time of Drake's landing there, by emphasising its precise location at 38 degrees of northerly latitude, and its having been acquired by Drake via voluntary submission by a local "Lord," with no evidence of any prior or active Spanish claim to the region. For Drake's claim to have had any legitimacy even to an English audience, the land had to be proven to be - in the words of Gilbert's patent - "not actually possessed of any Christian Prince or people." It is toward proving this un-possessed status that the bulk of Hakluyt's editorial labour in this section of his collection can be seen to have been directed.

The "Nova Albion" narrative begins with Drake, having already passed through the Straights of Magellan and ransacked a number of Spanish settlements on the Pacific coast of South America, pausing to carry out repairs on his ship at an island eight degrees north of the equator, before striking a final blow against a Spanish American possession, at Huatulco ("Guatulco") at fifteen degrees fifty minutes latitude. Seeking a route back to England, he chooses attempting to cross the Pacific and round the Cape of Good Hope rather than trying to retrace his outward route via the Straights. The remainder of the narrative, spanning a mere 1,800 words, records how he sails northward for a significant distance, southward again, lands, encounters the indigenous population, observes a ceremony among them which results in the spontaneous offer of dominion to

\footnotetext{
${ }^{15}$ For a discussion of this act of "pure linguistic formalism" see Greenblatt (1991:52$85)$.
} 
him, surveys the wealth of this new acquisition, and conducts his own ceremony of possession-taking.

The narrative concludes by suggesting: "It seemeth that the Spaniards hitherto had neuer bene in this part of the countrey, neither did euer discouer the land by many degrees to the Southwards of this place" (PN2 III:442). ${ }^{16}$ This is a curious sentence in the context of this item. Its sudden switch from reporting the events sequentially from an eye-witness perspective to articulating a much broader, definitively historical viewpoint marks a dramatic change in tone that is cut off (by the ending of the excerpt) as soon as it occurs. However this statement is also remarkably fragile, considering the key role it seeks or is made to play in buttressing the legitimacy of Drake's (and England's) right to engage in imperial activity in that region. There is superficial force in the doublyarticulated assertion that Spaniards "had never bene in" and "neither did ever" enter the area, augmented by the technicallytoned (though imprecise) buffer of "by many degrees to the Southwards." But the authority or even the origin of the statement as a whole is unsecured, clouded in the irrevocably ambiguous opening "It seemeth." In its bald functionality, this sentence embodies the drive apparent throughout the whole "Nova Albion" section to minimise and contain the extent of earlier Spanish explorations in nearby regions so as to secure the conceptual availability of the tract of land that Drake is reported to have accepted and claimed for England.

The framing of Nova Albion's availability is both a structural and a semantic operation. It employs all aspects of editorial control, from the broadest tools - selection, ordering, excerpting - to a much subtler, finer polishing - the rewording of individual phrases, or the addition of specific, short, timely marginal notes. The intertitle with which the "Nova Albion" section opens begins a process whereby it is suggested that a significant distinction be drawn between the achievements of Drake and those of his predecessors:

The First and Second Discouery of the gulfe of California, and of the Sea-coast on the Northwest or backside of America, lying to the West of New Mexico, Cibola and Quiuira, together with Sir

\footnotetext{
${ }^{16}$ This line is taken directly from the full 'Famous Voyage' narrative, and is not a fresh interpolation. See PN1 Sig. Mmm8 and PN2 III:738.
} 
Francis Drakes landing and taking possession vpon Noua Albion in the behalfe of the Crowne of England, and the notable voyage of Francis Gaule; Wherein amongst many other memorable matters is set downe the huge bredth of the Ocean sea from China and Iapan to the Northwest parts of America, in the 38. and 40. degrees. (PN2 III:397)

While recognition is given to the fact that others had ventured on missions of "discouery" in this region prior to that of the Englishman, only Drake's "taking possession" is acknowledged. This is a significant omission, since the narratives of both "The First and Second Discouer[ies]," led by Francisco de Ulloa ("Francis Vlloa") and Hernando de Alarcón ("Fernando Alarchon") respectively, contain numerous references to that specific type of action.

The Ulloa narrative recalls an exploratory expedition that took place in $1539-1540 .{ }^{17}$ Composed by Francisco Preciado, it explicitly describes ceremonies of possession-taking being performed at several locations, yet it is framed in a way that combats any suggestion that Drake's claim could have encroached on that of Ulloa (PN2 III: 399, 400, 401, 404, 420). ${ }^{18}$ Primarily, this is achieved through the addition of marginal notes to the Ulloa narrative in places where they do not occur in Hakluyt's acknowledged source, the third volume of Giovanni Battista Ramusio's collection of Navigationi et Viaggi (Ramusio 1556:3:339v-354). ${ }^{19}$ These notes help to systematically demarcate the limits of Ulloa's exploration, making clearer the extent to which Drake can be shown to have reached territory still unknown to Europeans - thirty eight degrees latitude, according to the intertitle of the Drake extract. In one such moment, which anticipates the careful framing of Drake as a surrogate for his

\footnotetext{
17 "A relation of the discouery, which in the Name of God the Fleete of the right noble Fernando Cortez Marques of the Vally, made with three ships; The one called Santa Agueda of 120. tunnes, the other the Trinitie of 35. tunnes, and the thirde S. Thomas of the burthen of 20. tunnes. Of which Fleete was Captaine the right worshipfull knight Francis de Vlloa borne in the Citie of Merida. Taken out of the third volume of the voyages gathered by M. Iohn Baptista Ramusio" (PN2 III:397-424).

${ }^{18}$ An alternative narrative of this expedition, under Ulloa's name, but not published by Ramusio, was accompanied by seven written acts of possession, formally notarised by Pedro de Palencia. See Wagner (1929:46-49).

${ }^{19}$ For a discussion of Hakluyt's engagement with Ramusio's text, see Small (2012:45$55)$.
} 
sovereign Elizabeth I, the narrative shows Ulloa symbolically performing the imperial speech-act within a context of two layers of superior authority: his immediate general Hernán Cortés, and their ultimate monarch, Charles V. " $[\mathrm{H}]$ ere the Captaine tooke possession for the Marques of the valley in the name of his Maiestie" (PN2 III:401). The marginal note here responds by confirming the location of this event as being well south of Drake's own, similar performance: "Ancon de S. Andres, or, The hauen of S. Andrew in 32 degrees." On another occasion, a pair of consecutive notes distil the narrative's account of attempting for two days to sail northward from the Isla de Cedros in difficult conditions into two cold statements: "Thirtie degrees of Northerly latitude" as the starting position, and "Twentie leagues beyond the Ile of Cedars" (i.e. less than a degree further north) as the finish. These notes occur only alongside Hakluyt's translation, not in his Italian source. ${ }^{20}$

A less subtle device impacting on the way in which the Ulloa narrative influences the reception of the Drake narrative is the unmarked interpolation of an entirely new paragraph to the end of the former's main body text:

Moreouer after the departure of the Santa Agueda for Nueua Espanna, the General Francis Vlloa in the ship called the Trinitie proceeding on his dicouery coasted the land vntill he came to a point called Cabo del Enganno standing in thirty degrees and a halfe of Northerly latitude, and then returned backe to Newspaine, because he found the winds very contrary, and his victuals failed him. (PN2 III:424)

As elsewhere in the narrative, this statement of quantifiable Spanish futility in pushing northward (relative to Drake's later achievement) inspires a marginal note recapitulating its facts: "Cabo del Enganno in 30 degrees \& a half." But there is an issue with this concluding paragraph: it has no counterpart in the source text. Rather it appears, like the marginal notes, to have been added to the Principal Navigations text specifically to demarcate the limit of Ulloa's exploration, and to preserve the un-possessed status of Nova Albion in anticipation of the subsequent Drake narrative. This form of

${ }^{20}$ I follow David and Alison Quinn in treating the 1556 edition of Ramusio's Navigationi et Viaggi as the source of the Ulloa and Alarcón narratives. See Quinn and Quinn (1974b:2:444-445). A reference to a woodcut of tall sea-weed on f. $353^{-\mathrm{v}}$ in that edition is present in the English translation, though this image is not. See PN2 III:424. 
interpolation is quite rare in The Principal Navigations. Unlike Ramusio, Hakluyt does not programmatically couch his materials in original discorsi or commentaries. That he chose to so blatantly - and so decisively - supplement the record here further demonstrates his investment in the framing of this section.

This process can be seen to continue as the sequence progresses to the narrative of a second conquistador, Alarcón, whose 1540 expedition to the head of the Gulf of California follows Ulloa's sequentially just as it did chronologically ( $\mathrm{PN}_{2}$ III:425-439; from Ramusio 1556:3:363-370-v). As a narrative of election to governorship by popular acclamation, the Alarcón text provides a useful precedent for Drake's claim to have been freely offered lordship over the people of "Nova Albion": at a key moment in the account a local leader is reported to instruct his countrymen, "This is our Lord [...] let vs willingly serve this lord, which wisheth vs so well" (PN2 III:431). Particularly encouraging to English Protestant audiences wishing to emulate Spanish conversion rates is a marginal note observing: "These people are greatly inclined to learne the Christian faith" (PN2 III:431). As it turns out, the version of Christianity apparently communicated by Alarcón to people with whom he shared little linguistic common ground was very light on doctrine: "And I tolde him that hee was in heauen, and that hee was called Iesus Christ, and I went no farther in diuinitie[...]" (PN2 III:430). Moreover, the version of "Christianity" to which they are allegedly "greatly inclined" is an oddly distorted form, featuring elements of a personal, paganistic cult. In this somewhat bizarre narrative, Alarcón is represented as spreading Christianity via a heretical fallacy of posing as the son of the sun, and in the process he is also offered dominion over this people:

Then he cryed out with a loud voyce and sayd, seeing thou doest vs so much good, and wilt not haue vs to make warre, and art the child of the Sunne, wee will all receive thee for our Lord, and alwayes serue thee. (PN2 III:429)

This declaration makes it clear that Alarcón has been accepted not for what he is (a mortal), but rather for what he has claimed to be (the progeny of a deity). Nonetheless, when the Nova Albion narrative shows Drake similarly benefitting from a spontaneous offer of sovereignty, this kind of behaviour seems more plausible 
than it would otherwise without the Alarcón narrative's having set a pattern for it to map onto.

Valuable as it is in providing almost a model for Drake's means of acquisition, however, it would have been counterproductive for the Alarcón narrative to risk being seen to pre-empt Drake's claim. A particularly threatening statement as regards the English claim occurs shortly before the end of the account, when the narrator attests "I bring with me many actes of taking possession of all that Coast" (PN2 III:439). With no references to latitude in the text to provide material from which to construct restrictive marginal notes, and in a context in which understanding of the geography of that part of the world was still far from complete, the possibility that Alarcón's acts of possession might provide a pretext for over-riding that of Drake could not be risked. Instead, an implied limit is supplied by the mechanism of inserting a short "extract of a Spanish letter written from Pueblo de los Angeles in Nueua Espanna in October 1597" (PN2 III:439). In this, more than forty folio pages of evidence of exploration by Ulloa and Alarcón is written off in the course of little more than one hundred and fifty words. Reporting that the viceroy of Mexico was preparing a fresh party of conquistadors to take possession of California in 1597, its implication is that almost two decades after Drake's taking possession of Nova Albion, Spain has never actually possessed this territory. For all that Spanish forces "haue bene sent [...] to conquer" to the North, the letter admits thy have always been "forced backe" (echoing Hakluyt's interpolation at the end of the Ulloa narrative), an apparent admission that the "actes of taking possession" by Ulloa and Alarcón were never solidified.

It is important to notice that this letter appears in an incorrect chronological position, upsetting Hakluyt's standard practice established across three folio volumes of allowing items within regional sections to follow each other in the simple order of time. Both the Drake narrative that follows it (1579) and the narrative of Francisco Gali ("Francis Gualle") that concludes the "Nova Albion" section (1582-1584) significantly pre-date the letter. This incongruity creates a tension in the volume's table of contents, where the letter is placed last in this section, in its correct chronological position, resulting in a disordering of the otherwise smoothly ascending sequence of page numbers (PN2 III: Sig. A6r-v). The letter's out-of- 
place insertion at this point in the Nova Albion sequence testifies to the anxiety that the Alarcón narrative in particular presents in terms of the question of precedence.

It is with this editorially-enhanced sense of California and the coast northward of it being as yet res nullius that this sequence finally arrives at the actual narrative of Drake's own imperial moment. When the people of Nova Albion, "making signes that they would resigne vnto him their right and title of the whole land, and become his subiects" are said to have offered Drake their "supplication that he would take their prouince and kingdom into his hand, and become their king," a context has been established showing the land to have been still legally un-possessed by European Christians ( $\mathrm{PN}_{2}$ III:441).

The care with which the conquistadors' northward push is delineated in this section - particularly in the Ulloa narrative, where the marginal notes continually keep track of landmarks' relative distance from each other in leagues - is put into sharp relief by a curious discrepancy between "The Famous Voyage" narrative and this "Nova Albion" extract. In both, Drake's journey as far north as Nova Albion is described as unplanned. Being at a certain moment becalmed, he is apparently left with no choice but to continue sailing northwards ("he saw that of necessitie hee must be forced to take a Spanish course, namely to sayle some what Northerly to get a winde," PN2 III:440). At this point the two narratives of the voyage diverge. While "The Famous Voyage" says they sailed "6oo. leagues at the least for a good winde," the "Nova Albion" narrative says Drake "sayled 800 leagues at the least" (PN2 III:737, 440). The difference is significant, in the order of six hundred miles, with the larger number greatly increasing the plausibility of the section's implied argument that Drake's "faire and good Bay" was clearly further north than any territory already claimed by Spain ( $\mathrm{PN}_{2}$ III:440).

It is admittedly impossible to prove that the change from 600 to 800 was deliberate. Given the vagaries of the hand-press process in sixteenth-century printing, allowance must inevitably be left for the possibility that the similarly-shaped numbers 6 and 8 may have simply been exchanged mistakenly. Such a slip could have been introduced by any one of the many people involved in the final production of the text, from Hakluyt himself, to one of the assistants 
Quinn suspects he may have had, to any of the surely many printers and apprentices who will have worked on a text of this size (Hakluyt 1965:1:xviii-xx). Yet it seems extraordinary that this politically very sensitive error should have made it into circulation unnoticed. Julia Schleck rightly advises caution when assuming the extent of Hakluyt's "high documentary standards," but an error of this importance nonetheless seems incompatible with the care taken to correct another, relatively insignificant sequential mix-up in the "Nova Albion" narrative during its extraction from the longer "Famous Voyage" account (2006:788). That the shorter extract was scrutinised and, where necessary, altered in preparation for its independent resetting is apparent from the re-ordering of the moments at which Drake conducted his attack on Huatulco and the repair of his ship at the Isle of Cano. In the "Famous Voyage" narrative it appears that the repairs at Cano, which lies off the coast of Costa Rica, were undertaken only after the sacking of Huatulco (PN2 III:736). The versions of "The Famous Voyage" narrative in both editions of The Principal Navigations agree on this point. ${ }^{21} \mathrm{~A}$ contrasting view, however, is found in a report of English activities in the New World by the Portuguese captive Lopez Vaz, also printed in The Principal Navigations, which includes a section on Drake's circumnavigation in which the Cano stopover is described as preceding the Huatulco raid (PN2 III:793). Vaz claims to have based this part of his history on the testimony of the experienced Portuguese pilot and navigator, Nuño da Silva, who accompanied Drake through the Straights of Magellan as a prisoner, and whose own narrative appears immediately following "The Famous Voyage" in the 1600 volume (PN2 III:742-748). The Silva text affirms Vaz's sequence (PN2 III:747). ${ }^{22}$ This question of sequence becomes significant when it is observed that, in spite of its having been sourced from "The Famous Voyage," the "Nova Albion" narrative agrees instead with the Silva/Vaz chronology in placing the Cano stop before the Huatulco raid (PN2 III:440). Were the "Nova Albion" narrative to be merely cosmetically different from its source, it

\footnotetext{
${ }^{21}$ The island at which Drake's party effect their repairs is called "the island of Canon" in the 1589 text, and is identified as "The Island of Cockles" in the marginal note, but all refer to the same event. See $P N_{1} 643 \mathrm{H}$

${ }^{22}$ Although the Silva narrative never actually mentions Cano by name, a positive identification is made in the margin, supplying further evidence of these having been created with analytical, rather than simply emphatic, intent.
} 
would suggest little of consequence. A factual amendment, however, indicates that the preparation of the "Nova Albion" text involved a more thorough process of revision and a deeper level of scrutiny. The fact that this sequential error has been corrected in the "Nova Albion" text demonstrates that the text of "The Famous Voyage" was re-evaluated, either with reference to maps or else in comparison with the evidence of Silva/Vaz. The degree of care taken over this relatively unimportant detail raises makes the existence of the $600 / 800$ slip particularly remarkable.

The final item in the "Nova Albion" section contributes both to the overall argument of the section as it is framed, and also to the visibility of this framing (PN2 III:442-447). Taken from the 1598 English translation of the Dutch merchant Jan Huyghen van Linschoten's 1596 Itinerario (a source which, like Ramusio's Navigationi et viaggi, Hakluyt draws on several times in The Principal Navigations), this is a narrative of the voyage of Gali across the Pacific from Mexico to Southeast Asia and back between 1582 and 1584 (Linschoten 1598:411-416). ${ }^{23}$ Since its destination and the area on which it focuses for two of its three chapters (approximately three-quarters of its length) is not California, but rather the Philippines and Macau, it is out of place in Hakluyt's collection - not chronologically, as in the letter from Pueblo de los Angeles, but rather geographically. It would belong more properly either closer to the end of the third volume, among the longer circumnavigation voyages of Drake and Thomas Cavendish (which follow similar routes across the Pacific), and the Portuguese Jesuit Luís Fróis's discussions of affairs in East Asia, or in the second part of the second volume, with Peter Martyr d'Anghiera's reports on China and Japan. Either of these more geographically-appropriate locations would make a greater proportion of the information it contains more easily and usefully accessible. Its inclusion in the "Nova Albion" section therefore suggests that the information it provides on the American coast of the Pacific must serve some particular function in that specific context.

As elsewhere in this section, the paratextual framing of this narrative would seem to support this assumption. Although the original Dutch edition of the Itinerario includes numerous printed

\footnotetext{
${ }^{23}$ Chapters 1-3 in the Hakluyt version are Chapters 52-54 in Linschoten.
} 
marginal notes, these are absent in the English edition which Hakluyt used as his source. The appearance of marginal notes in the version of the Gali narrative in The Principal Navigations therefore suggests creative design rather than mechanical, printing-house retransmission. This seems particularly so once the relative paucity of marginal annotation in the first two chapters (dealing with the outward voyage and observations of Southeast Asia) is contrasted with the sudden density of notes accompanying the third chapter. The first of a key cluster occurs just as Gali is describing his first (and most northerly) point of contact with the North American coast on his return voyage. It reads "Iapon 90o. leagues distant from the coast of America in 37 degrees and an halfe" (PN2 III:446). The two facts in this short note serve two different agendas. The reference to " 900. leagues" emphasizes Gali's observation that the Northern Pacific was much wider and more open than previously thought. This discovery made more plausible hopes for a Northeast or Northwest Passage, which for Hakluyt's purposes would eliminate the need to traverse Spanish waters to reach eastern trading partners - not to mention this new possession of Nova Albion. This would increase the potential value of Drake's acquisition and therefore also its attractiveness to future investors. ${ }^{24}$ Hakluyt's investment in this argument is evidenced by the entry for the Gali narrative in the volume's table of contents:

The memorable voyage of Francis Gualle a Spanish captaine and pilot, vndertaken at the appointment of the viceroy of New Spaine, from the hauen of Acapulco in the sayd prouince, to the islands of the Luçones or the Philippinas, vnto the hauen of Manilla, and from thence to the hauen of Macao in China; and from Macao by the Lequeos, the isles of Iapan, and other isles to the East of Iapan, and likewise by the Northwest part of America in 37 degrees and $1 / 2$ backe againe to Acapulco, begun the 10 of March 1582, \& ended 1584. Out of which voyage, besides great probabilities of a North, Northwest, or Northeast passage, may euidently be gathered, that the sea betweene Iapan and America is by many hundred leagues broader, and the land betweene Cape Mendoçino and Cape California, is many hundred leagues narrower, then we finde them to be in the ordinary maps and relations. (PN2 III: Sig.A6r-v)

${ }^{24}$ Hakluyt included a series of documents concerning the Northeast Passage and English voyages in its direction toward the end of the first volume of his collection. See $P N_{2}$ I:509-514. 
From the beginning until the dates of the voyage, this is taken almost word for word from the on-page intertitle, which itself is simply replicating the corresponding intertitle in the English edition of Linschoten's Itinerario. The final passage however, goes far beyond the standard function of a contents entry (stating the name of the voyager, the route or destination, and the date travelled), by concluding with a statement of the significance of this text in terms of wider navigational debates.

The only other significant addition to the intertitle sourced from the Linschoten text in the contents entry is the reference to the critical number " 37 degrees and $1 / 2$." The importance of this figure to Hakluyt is readily apparent in the fact that it - not the latitude of Manila, Macau or any of the other Asian destinations - is the only one to receive mention here, but its sensitivity becomes much more apparent in the context of the cluster of marginal notes discussed above. As it happens, this latitude is not actually mentioned in the immediate vicinity of the "90o. leagues" note, making it an external addition to Gali's testimony at this point. In fact, when it does occur a few lines later it is actually accompanied by a marginal note of its own, stating for a second time the crucial co-ordinate of "Seuen and thirty deg. and an halfe" (PN2 III:446). This use of two marginal notes to highlight the same fact betrays its crucial importance. For these repeated references to $37^{1 / 2}$ degrees are a continuation of earlier efforts in this section to pen Spanish activity below the 38 degrees level of Nova Albion, defending the principle of Drake's claim even though he left no occupying force to secure it. The particular care with which this margin is defended in this instance perhaps also reflects its narrowness, with half a degree of latitude equalling only a little over 30 miles.

That the Gali narrative is an integrated element in the framing of Nova Albion is clear from the next note in this cluster. While Gali is precise about the latitude of his landfall, he does not refer to it by any name. Instead it is distinguished in his narrative by a particular natural phenomenon, certain offshore "drifts of rootes, leaues of trees, reeds, and other leaues like figge leaues." By means of a marginal direction to "Read Francis Vlloa chap. 16," Hakluyt seems to link this observation with the tall sea-growing weeds discussed twice in Ulloa as being in the vicinity of the Isla de Cedros, at the much safer remove from Nova Albion of " $28 \mathrm{deg}$. and a quarter" 
(PN2 III:418, 424). Hakluyt is here explicitly leading his readers to engage with a framework of cross-references between the various component texts in this section, a process which will lead them to create a mental map of this disputed region based primarily on the co-ordinates and conclusions to which he has given prominence.

Gali's progress away from Nova Albion continues to be tracked in the next marginal note, as his journey south is stated to have taken him to "Cabo de San Lucas in 22. deg.," but it is the following note which proves particularly helpful to the establishment of a case that Spain had never been in a position to stake a claim to Nova Albion prior to Drake's. The text at this point describes three havens at latitudes of $30^{3 / 4}, 28 \frac{1}{4}$, and $23^{1 / 2}$ degrees - all safely below the critical 38 degree level - and helpfully describes them as "now lately found out." This testimony, dated several years after Drake's Pacific activities, would seem to confirm that the Spanish had only recently achieved even this limited knowledge. Typically (at least for this section of The Principal Navigations) this inference is emphasised in the marginal note's echoing "Hauens lately found out."

Drake's right to claim Nova Albion for England is validated throughout this sequence by the suggestion that Spanish efforts to establish authority had been limited in terms not only of their success, but particularly of their scope. The marginal notes in the Ulloa and Gali narratives, and the letter from Pueblo de los Angeles, firmly demarcate the extent of Spanish progress, so as to define Nova Albion as territory over which no European had established authority.

It should always be remembered, however, that The Principal Navigations is a complex text composed of a heterogeneous array of components. This analysis of a specific cluster of these component texts is not presented as being typical, or even especially representative, of the wider collection. It shows how paratextual framing could, along with more intrusive editorial techniques, be used to try to marshal a series of discrete items in order to bolster a particular view of English navigational success. However, while most of these techniques are visible (at a much lower density) elsewhere in the collection, the evident care with which this particular section can be seen to have been assembled is exceptional. If nothing else, the prohibitive size of the collection seems to have prevented the level of sustained shaping and polishing visible here 
from having been implemented consistently. That in itself renders the care on display in this section all the more significant. For all the time and energy that he spent and would spend before and after the publication of his great collections in promoting English settlement along North America's Atlantic coast, here it is to this question of Nova Albion that Hakluyt devotes the most exceptional, obvious effort.

It is unnecessary here to attempt to define Hakluyt's ultimate goal in framing this section as he did. David Harris Sacks (2006) and David Boruchoff (2009) both sensibly caution against assuming exclusively secular motivations for his editorial labours, but there were certainly also solid geopolitical reasons why England would have wished to acquire a foothold in the Americas beyond the reach of Spanish control. Whatever the immediate motivation, or combination of motivations, it is certain that the textual traces discussed above convey the contours of Hakluyt's engagement with this set of materials at least as surely as they are made to demarcate the limits of Spanish exploration in the region they describe.

\section{References}

Borge, Francisco J. 2012. "'We (upon peril of my life) shall make the Spaniard ridiculous to all Europe': Richard Hakluyt's 'Discourse' of Spain." Eds. Daniel Carey and Claire Jowitt. Richard Hakluyt and Collected Travel Writing in Early Modern Europe. Aldershot: Ashgate: 167-176.

Boruchoff, David A. 2009. "Piety, Patriotism, and Empire: Lessons for England, Spain, and the New World in the Works of Richard Hakluyt." Renaissance Quarterly 62/3: 809-858.

Elliott, J. H. 1968. Europe Divided 1559-1598. London: Fontana.

Fuller, M. C. 1995. Voyages in Print: English Travel to America, 1576-1624. Cambridge: Cambridge University Press.

Greenblatt, Stephen 1991. Marvelous Possessions: The Wonder of the New World. Oxford: Clarendon Press.

Hakluyt, Richard 1589. The Principall Navigations, Voiages, and Discoveries of the English Nation. London: G. Bishop, R. Newberie and C. Barker.

— 1598-1600. The Principal Navigations, Voyages, Traffiques and Discoveries of the English Nation. 3 vols. London: G. Bishop, R. Newberie and R. Barker. 
1965 (1589). The Principall Navigations, Voiages, and Discoveries of the English Nation: Facsimile of the 1589 Edition. Eds. D. B. Quinn and R. A. Skelton. 2 vols. Cambridge: MacLehose.

1993 (1584). A Particuler Discourse Concerninge the Great Necessitie and Manifolde Comodyties That Are Like to Growe in This Realme of Englande by the Westerne Discoueries Lately Attempted. Eds. D. B. Quinn and A. M. Quinn. London: The Hakluyt Society.

Jane, Cecil trans. and ed. 1988. The Four Voyages of Columbus: A History in Eight Documents, Including Five by Christopher Columbus. New York: Dover.

van Linschoten, Jan Huyghen 1598. John Huighen van Linschoten, His discours of voyages into ye Easte and West Indies: deuided into foure bookes. London: John Wolfe.

MacCrossan, Colm 2012. "Framing 'the English nation': Distinguishing Text and Paratext in The Principal Navigations (1598-1600)." Eds. Daniel Carey and Claire Jowitt. Richard Hakluyt and Collected Travel Writing in Early Modern Europe. Aldershot: Ashgate: 139-151.

MacMillan, Ken 2006. Sovereignty and Possession in the English New World: The Legal Foundations of Empire, 1576-1640. Cambridge: Cambridge University Press.

Pirillo, Diego 2012. "Balance of Power and Freedom of the Seas: Richard Hakluyt and Alberico Gentili." Eds. Daniel Carey and Claire Jowitt. Richard Hakluyt and Collected Travel Writing in Early Modern Europe. Aldershot: Ashgate: 177-186.

Ramusio, Giovanni Battista 1556. Navigationi et Viaggi. Venice: Stamperia de Giunti.

Sacks, David Harris 2006. "Richard Hakluyt's Navigations in Time: History, Epic, and Empire." Modern Language Quarterly 67/1: 31-62.

Schleck, Julia 2006. "Plain Broad Narratives of Substantial Facts': Credibility, Narrative, and Hakluyt's Principall Navigations." Renaissance Quarterly 59/3: 768-794.

Small, Margaret 2012. "A World Seen Through Another's Eyes: Hakluyt, Ramusio, and the Narratives of the Navigationi et Viaggi." Eds. Daniel Carey and Claire Jowitt. Richard Hakluyt and Collected Travel Writing in Early Modern Europe. Aldershot: Ashgate: 45-55.

Quinn, D.B. 1967. Richard Hakluyt, Editor: A Study Introductory to the Facsimile Edition of Richard Hakluyt's Divers Voyages (1582). Amsterdam: Theatrum Orbis Terrarum.

— 1974b. "Contents and Sources." Ed. D.B. Quinn. The Hakluyt Handbook. 2 vols. London: The Hakluyt Society: 333-46o. 
C. MacCrossan

— and A.M. Quinn 1974a. "A Hakluyt Chronology." Ed. D.B. Quinn. The Hakluyt Handbook. 2 vols. London: The Hakluyt Society: 263-331.

Wagner, Henry Raup, ed. 1929. Spanish Voyages to the Northwest Coast of America in the Sixteenth Century. San Francisco: California Historical Society.

Wernham, R. B. 1951. "Queen Elizabeth and the Portugal Expedition of 1589." The English Historical Review 66/258: 1-26 and 66/259: 194-218.

How to cite this article:

MacCrossan, Colm. "Framing 'Nova Albion': Marking possession in Richard Hakluyt's The Principal Navigations, Voyages, Traffiques and Discoveries of the English Nation." SEDERI 24 (2014): 47-68.

Submission: 05/11/2013

Acceptance: $26 / 04 / 2014$ 